Project Report

\title{
Production of Biodiesel from Waste Cooking Oil via Deoxygenation Using Ni-Mo/Ac Catalyst
}

\author{
Nor Shafinaz Azman ${ }^{1}\left(\mathbb{D}\right.$, Tengku Sharifah Marliza ${ }^{1,2, *}$, Nurul Asikin Mijan ${ }^{3}$, Taufiq Yap Yun Hin ${ }^{2,4}$ \\ and Nozieana Khairuddin $1, *$ (i) \\ 1 Department of Basic Science and Engineering, Faculty of Agriculture and Food Sciences, Universiti Putra \\ Malaysia Bintulu Sarawak Campus, Bintulu 97008, Malaysia; gs56703@student.upm.edu.my \\ 2 Catalysis Science and Technology Research Centre, Faculty of Science, Universiti Putra Malaysia, \\ UPM Serdang, Serdang 43300, Malaysia; taufiq@upm.edu.my \\ 3 Department of Chemical Sciences, Faculty of Science and Technology, Universiti Kebangsaan Malaysia, \\ UKM Bangi, Bangi 43600, Malaysia; nurul.asikin@ukm.edu.my \\ 4 Chancellery Office, Universiti Malaysia Sabah, Kota Kinabalu 88400, Malaysia \\ * Correspondence: t_marliza@upm.edu.my (T.S.M.); nozieana@upm.edu.my (N.K.); Tel.: +60-86-855-430 (N.K.)
}

Citation: Azman, N.S.; Marliza, T.S.; Mijan, N.A.; Yun Hin, T.Y.; Khairuddin, N. Production of Biodiesel from Waste Cooking Oil via Deoxygenation Using Ni-Mo/Ac

Catalyst. Processes 2021, 9, 750.

https: / dx.doi.org/10.3390/ pr9050750

Received: 12 November 2020

Accepted: 6 December 2020

Published: 23 April 2021

Publisher's Note: MDPI stays neutral with regard to jurisdictional claims in published maps and institutional affiliations.

Copyright: (c) 2021 by the authors. Licensee MDPI, Basel, Switzerland. This article is an open access article distributed under the terms and conditions of the Creative Commons Attribution (CC BY) license (https:// creativecommons.org/licenses/by/ $4.0 /)$

\begin{abstract}
Waste cooking oil (WCO) from palm oil is one of the most prospective biodiesel feedstock when compared to other oil seeds. Thus, WCO has great potential as a green source of diesel fuel for engines in motor vehicles and machinery. This project aimed to study the potential of three randomly selected types of WCO, namely; sample A (used $1 \times$ once to fry an egg), sample B (used 3$5 \times$ to fry salted fish), and sample $C$ (used repeatedly to fry banana fritter) for the production of green diesel fuel over Ni-Mo/AC (nickel and molybdenum oxides incorporated with activated carbon) catalyst through the deoxygenation (DO) process. The prepared catalyst was characterized through X-ray diffraction (XRD), thermogravimetric analysis (TGA), and field emission scanning electron microscopy (FESEM). The DO process was performed at $350{ }^{\circ} \mathrm{C}$ to remove oxygen from the WCO samples. The liquid products were analysed by gas chromatography-mass spectrometer (GC-MS) and gas chromatography-flame ionization detector (GC-FID), to measure the yields of straight-chain hydrocarbons and fractions in the range $\mathrm{C}_{8}-\mathrm{C}_{20}$. Results showed that the highest $n-\left(\mathrm{C}_{8}-\mathrm{C}_{20}\right)$ hydrocarbon fractions were produced in the order of sample $\mathrm{B}(89.93 \%)>\mathrm{C}(88.84 \%)>\mathrm{A}$ $(82.81 \%)$.
\end{abstract}

Keywords: waste cooking oil; green fuel; biodiesel; heterogeneous catalyst; deoxygenation

\section{Introduction}

Current strategies are geared towards a green form of diesel consisting of freeoxygenated hydrocarbon compounds for future use as a clean-burning fuel. Such fuels are characterised by low sulphur and aromatic content, high cetane content, lubricity and regenerability, which can guarantee $\sim 70-90 \%$ reduction in GHG emissions (Asikin-Mijan et al., 2016a). Since the substance is not only fungible with crude oil-derived fuels, it also has properties similar to alternative biofuels, such as biodiesel or methyl ester fatty acid (FAME). FAME is an extremely oxygenated compound with various drawbacks, such as high viscosity, low cloud and pour point properties, along with low heating value and oxidation stability [1-3]. Green diesel is generally synthesized by the deoxygenation (DO) of triglycerides and fatty acid derivatives by decarboxylation or decarbonylation (deCOx), along with the formation of $\mathrm{CO}_{2}$ and $\mathrm{CO}+\mathrm{H}_{2} \mathrm{O}$ as by-products [4-6]. Green diesel may also be synthesized by the process of hydrodeoxygenation (HDO), during which oxygenated compounds are extracted in the presence of $\mathrm{H}_{2}$ gas, resulting in the formation of water $\left(\mathrm{H}_{2} \mathrm{O}\right)$ as a by-product [7]. However, the process requires a high amount of expensive $\mathrm{H}_{2}$ gas and high reaction pressure [8]. In contrast, the DO procedure is considered to be more economical, successful and suitable for industrial practices. The process results 
in high-quality green diesel, with similar fuel properties as standard crude oil-derived diesel [9].

Recently, the DO process was investigated using various catalysts, such as Pd or Ptbased transition metal oxides consisting of $\mathrm{Ni}, \mathrm{Co}, \mathrm{Zn}, \mathrm{Cu}, \mathrm{Ga}$ and $\mathrm{Ru}[2,10-13]$. The most typical transition metal oxides used for $\mathrm{DO}$ are $\mathrm{Ni}, \mathrm{Co}, \mathrm{W}$ [14], and $\mathrm{Mo}, \mathrm{Cu}, \mathrm{Fe}$, and $\mathrm{Zn}$ [15], with $\mathrm{Ni}$ showing the highest $\mathrm{DO}$ behaviour among the metals. Croker and co-workers observed that $20 \mathrm{wt}$. per cent $\mathrm{Ni} / \mathrm{C}$ yielded higher glycerol tristearate compared to $5 \mathrm{wt}$. percent $\mathrm{Pd}$ and $1 \mathrm{wt}$. percent Pt-promoted catalyst [16]. The results are important since $\mathrm{Ni}$ is $\sim 1750$ and $\sim 3450$ times cheaper than $\mathrm{Pd}$ and Pt, respectively. A few studies have shown that Ni-promoted catalysts exhibited high DO activity through the deCOx pathway during the DO phase of triglyceride oil and model compounds (palmitic acid methyl group stearate) for the production of diesel-range hydrocarbons [17]. The efficacy of the DO reaction mainly includes noble-based catalysts on either $\mathrm{Pd}$ or $\mathrm{Pt}$, which result in high deCOx activity and high hydrocarbon fraction yields. However, the high cost of such catalysts restricts industrial applications. Another downside for large-scale applications is the complex method of preparing such catalysts. The acid-based catalysts are also vulnerable to deactivation of the catalytic active sites due to coke formation [18]. The modification of such catalysts is therefore an essential requirement to enhance stability. Recent studies have shown that lower coke formation is accomplished by the use of basic metal-catalyst compared to acid metal-catalysts during DO reactions [1,4]. However, despite the existence of high cracking activity, the fundamental catalyst jointly results in low deCOx activity $[4,19]$. The acidic-basic properties of disaggregated $\mathrm{CaO}-\mathrm{La} 2 \mathrm{O} 3 / \mathrm{AC}$ nano-sized carbon-supported catalysts have been effective in the development of biodiesel [19]. The catalytic properties of mixed metal oxides are mostly reliant on the microstructure of the nanosized catalyst. During the nanoparticle stage, the surface-to-volume ratio increases significantly, meaning that the surface atoms absorb an increasing fraction of the entire particulate volume with high defective structures. As a consequence, the atoms show interesting new or enhanced chemical properties. Nanocrystalline $\mathrm{NiMoO} 4$, with a particle size of about $20 \mathrm{~nm}$, has been synthesized [20,21], but no catalytic information has been published in the literature. Furthermore, the development and comprehensive examination of catalysts by researchers for industrial biodiesel application are yet to be achieved. The high cost of raw materials is a major obstacle for the commercialization of biodiesel production [22]. Hence, the use of cheap and renewable feedstocks is crucial to the production of biodiesel. Waste cooking oil (WCO) is an abundant by-product of daily food preparation [23]. The use of palm oil-based WCO as feedstock for biodiesel could jointly solve the problems of waste disposal and dwindling environmental standards in Malaysia.

In the current research, the selective catalytic synthesis of stable mesoporous compounds was investigated through DO, using an acidic bimetallic Ni-Mo/AC OXIDE catalyst. The synthesized catalyst was characterized by XRD, TGA, field emission scanning electron microscopy (FESEM) and FTIR. The products obtained were subsequently characterized by GC-MS and GC-FID to investigate the effect of the various palm oil-based WCOs. The selected catalyst for the great performance breakdown of hydrocarbon chains was synthesized at the recommended ratio of 10\%:10\%:80\%, due to higher AC usage compared to the acid and basic metal. The paper provides useful information on the evaluation of WCO from various food types, preparation and frequency of use through DO using a prepared catalyst.

\section{Materials and Methods}

\subsection{Materials}

The AC was purchased from Sigma-Aldrich with the appearance of the 100-400 mesh as support. The nickel (II) nitrate hexahydrate $\left(\mathrm{Ni}\left(\mathrm{NO}_{3}\right)_{2} \cdot 6 \mathrm{H}_{2} \mathrm{O}\right)$ with molecular weight $290.79 \mathrm{~g} / \mathrm{mol}$ and ammonium molybdate $\left(\left(\mathrm{NH}_{4}\right)_{6} \mathrm{Mo}_{7} \cdot 4 \mathrm{H}_{2} \mathrm{O}\right)$ with molecular weight $1235.86 \mathrm{~g} / \mathrm{mol}$ were purchased from HmbG Chemicals. The liquid product used was phosphoric acid (lab-grade standard in $85 \%$ ) from the Reagent brand. The experimental 
palm oil-based WCO feedstock was obtained from a selected café and stall located at Serdang in Selangor, Malaysia. The three treatments were arranged based on the number of uses of the WCO, as shown in Table 1. The oils used for the reactions were applied directly without any treatment or purification.

Table 1. Sample of waste cooking oil and the number of times used before treatment.

\begin{tabular}{ccc}
\hline Sample & Number of Times Used & Types of Usage \\
\hline A & 1 time & Fried egg \\
B & $3-5$ times & Fried salted fish \\
C & $>5$ times & Fried banana fruit fritter \\
\hline
\end{tabular}

\subsection{Catalyst Synthesis}

Catalyst preparation for this research was prepared by following the method of Wan Khalit et al. [24] with minor modification. The reflux apparatus shown in Figure 1 was set up in a fume chamber equipped with water flow for the inlet and an outlet for the excess distilled water discharged. The heating and stirrer machines were connected with a retort stand to hold the reflux condenser upward, together with the temperature detector rod placed inside the stainless-steel basin placed on the heater. The $250 \mathrm{~mL}$ round bottom flask was immersed in paraffin liquid to avoid rapid evaporation due to the heating effect. Next, precisely $5 \mathrm{~g}$ of the AC was weighed using a digital balance, while $75 \mathrm{~mL}$ of phosphoric acid was measured using a measuring cylinder. Both materials were transferred to a $250 \mathrm{~mL}$ round bottom flask and a magnetic stirrer was placed in the flask before connecting a reflux condenser to the lower part. The hot plate was then set to $150{ }^{\circ} \mathrm{C}$ and $500 \mathrm{rpm}$ for $12 \mathrm{~h}$. The purification of the heated substances using warm distilled water was done after adjusting the solution to $\mathrm{pH} 7$. Next, the powder was dried in an oven at $100{ }^{\circ} \mathrm{C}$ for $2 \mathrm{~h}$. The AC was then impregnated to synthesize the NiO: MoO: AC catalyst based on the w/w ratio $10 \%: 10 \%: 80 \%$, by constant stirring for six (6) hours. The impregnated metals on the catalyst support were subsequently desiccated at $100{ }^{\circ} \mathrm{C}$ for $24 \mathrm{~h}$. Afterwards, AC doped with the metals was calcined under $\mathrm{N}_{2}$ gas flow at $700{ }^{\circ} \mathrm{C}$ for $4 \mathrm{~h}$.

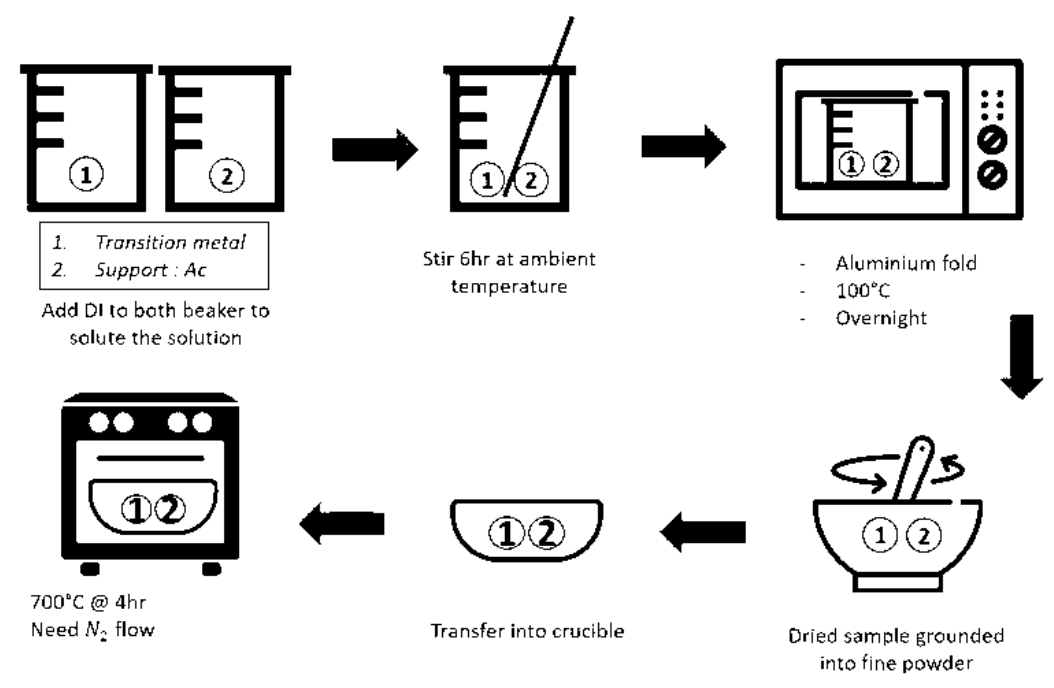

Figure 1. Schematic diagram for catalyst synthesis by wet impregnation method.

\subsection{Catalyst Characterization}

\subsubsection{X-ray Diffraction (XRD)}

In this study, XRD was utilized to determine the rate of dispersion and the chemical structure of the reformed AC catalyst, before and after the reaction. The XRD inquiry was carried out on the Shimadzu diffractometer (Model: XRD-6000, Shimadzu Corporation, Kyoto, Japan). 


\subsubsection{Thermogravimetric Analysis (TGA)}

TGA analysis was used to test the stability of the synthesized catalysts. It was also used to examine the coke deposition on the spent catalysts. Each spent catalyst was heated at $30{ }^{\circ} \mathrm{C} / \mathrm{min}$ heating rate under the oxygen gas $\left(\mathrm{O}_{2}\right)$ flow rate of $40 \mathrm{~mL} / \mathrm{min}$, from $25^{\circ} \mathrm{C}$ to $900^{\circ} \mathrm{C}$.

\subsubsection{Field Emission Scanning Electron Microscopy (FESEM)}

The morphological characteristics of the catalyst were investigated by field emission scanning electron microscopy (Rayny EDX-720; Shimadzu, Kyoto, Japan). The FESEM images were observed through the LEO 1455 VP electron microscope.

\subsubsection{Fourier Transform Infrared (FTIR) Spectroscopy}

The FTIR analysis was conducted to analyse the chemical functional groups of the triolein (feedstock) and deoxygenated materials. During the deoxygenation cycle, the absorption bands corresponding to the ester, alcohol, carbonyl, glycerides, and carboxylic groups were recorded. Chemical characterization analysis was done following the method described by Muhamad et al. (2013) with minor modification. The Perkin-Elmer Spectrum One FT-IR Spectrometer was used to examine the chemical composition and chemical bonds present in the prepared films. Before the FTIR analysis, the prepared films were dried overnight at $40{ }^{\circ} \mathrm{C}$ in an oven. Each dried film was then ground into a fine powder. Next, $4 \mathrm{mg}$ of the ground films were mixed with potassium bromide $(\mathrm{KBr})$ powder in a ratio of 1:10. The sample pellets were formed under a pressure of $500 \mathrm{~kg} / \mathrm{cm}^{2}$ using a hydraulic press. The prepared samples were then analysed using the Perkin-Elmer Spectrum One FT-IR Spectrometer at a resolution of $4 \mathrm{~cm}^{-1}$ in the range of $4000-400 \mathrm{~cm}^{-1}$ averaged over 16 scans.

\subsection{Catalyst Performance Evaluation}

\subsubsection{Catalytic Deoxygenation of Waste Cooking Oil (WCO)}

The DO of WCO was performed in a $250 \mathrm{~mL}$ mechanically stirred, semi-batch reactor, as shown in Figure 2. For each run, $10 \mathrm{~g}$ of WCO and $5 \mathrm{wt} . \%$ of the synthesized catalyst were placed in the reactor, as reported by Wan Khalit et al. [24], who stated that the reactor must be purged with $\mathrm{N}_{2}$ gas to extract the $\mathrm{O}_{2}$ from the air created during the heating process, by setting the temperature to $350^{\circ} \mathrm{C}$ and run-time of $3 \mathrm{~h}$. The condensed liquid product was subsequently deoxygenated and stored in the collection vessel placed after the chiller. After the reaction was completed, the reactor was cooled to an ambient temperature, while the contents of the vessel collector and round bottom flask were weighed [10]. Lastly, the products were analysed by gas chromatography-flame ionization detection (GC-FID).
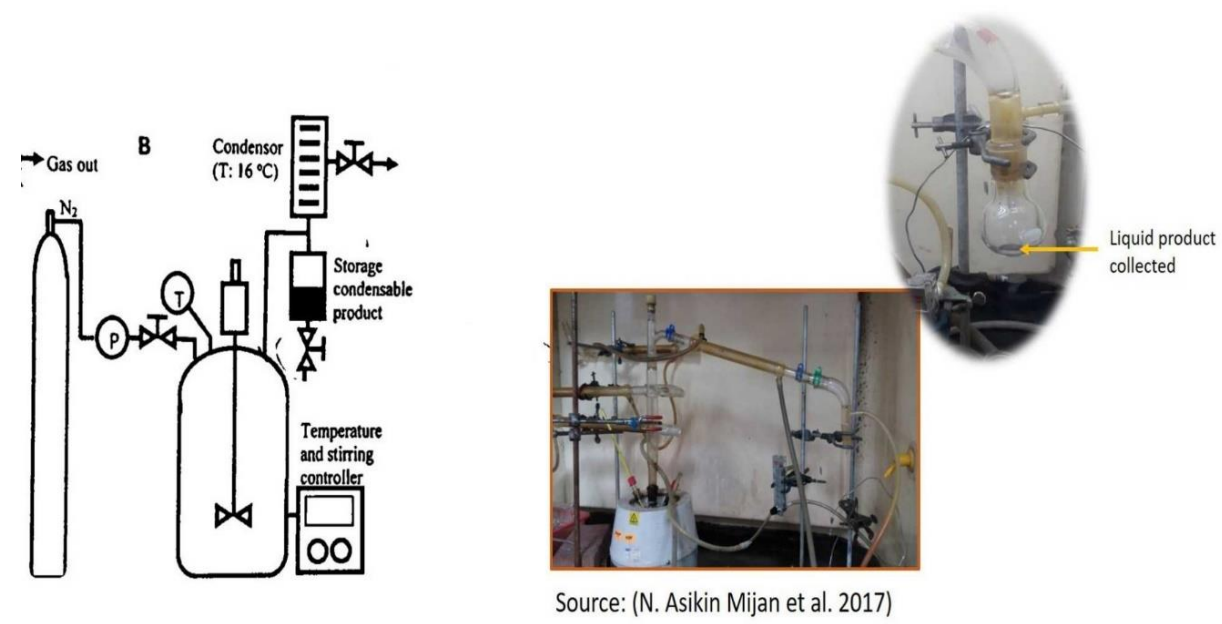

Figure 2. Semi-batch schematic diagram and process setup for deoxygenation of waste cooking oil (WCO). 


\subsubsection{Gas Chromatography-Flame Ionization Detector (GC-FID)}

The liquid-based products were examined by GC-FID. Before each test, the sample was dissolved in the GC standard $n$-hexane before $1 \mu \mathrm{L}$ of the sample aliquot was inserted in the GC column. Simultaneously, the temperature of the injection was fixed at $250{ }^{\circ} \mathrm{C}$, whereas nitrogen was selected as the transport gas. The oven of the GC-FID was set to $6 \mathrm{~min}$ at $40^{\circ} \mathrm{C}$, before ramping to $300^{\circ} \mathrm{C}$ at a rate of $7{ }^{\circ} \mathrm{C} / \mathrm{min}$ for $30 \mathrm{~min}$. The GCFID analysis was performed to define the hydrocarbon components from the marketed saturated versions from $\mathrm{C}_{8}-\mathrm{C}_{20}$ and the commercially unsaturated nonene [5]. The entire area under the chromatographic peak of each hydrocarbon fraction (\% relative abundance) also termed the total saturated and unsaturated straight-chain hydrocarbons $\left(\mathrm{C}_{8}-\mathrm{C}_{20}\right)$ ( $n$-alkane $+n$-alkene) fractions, were determined by Equation (1):

$$
X=\frac{\sum A_{o}+\Sigma A_{i}}{\Sigma A_{z}} \times 100 \%
$$

The term $X$ denotes the saturated and unsaturated straight-chain hydrocarbon fractions (\% relative abundance), $A_{o}$ was determined by the area of the alkene $\left(\mathrm{C}_{8}-\mathrm{C}_{20}\right), A_{i}$ was determined by the area of the alkane $\left(\mathrm{C}_{8}-\mathrm{C}_{20}\right)$, and $A_{z}$ was determined by the area of the total product.

\subsubsection{Gas Chromatography-Mass Spectrometer (GC-MS)}

GC-MS was employed to evaluate the liquid deoxygenated substances with the saturated and unsaturated hydrocarbon $\left(\mathrm{C}_{8}-\mathrm{C}_{20}\right)$ fractions defined under experimental conditions. Asomaning [25] demonstrated that the identification of the unsaturated hydrocarbons can be performed by interpreting the GC-MS based data and comparing it to the National Institute of Standards and Testing Library and Literature data. Asikin-Mijan [26] reported that the chemical composition of the feedstocks and liquid products of $\mathrm{DO}$ were characterised qualitatively by the GC-MS (Shimadzu QP50550A model) equipped with a non-polar DB-5HT column $(30 \mathrm{~m} \times 0.32 \mathrm{~mm} \times 0.25 \mu \mathrm{m})$ through the less split inlet. The completed examination is significant since the resulting liquid product was then assumed to have functions that are not limited to hydrocarbons. The samples were diluted to $100 \mathrm{mg} / \mathrm{L}$ with GC grade $n$-hexane (purity $>98 \%$ ), while the compounds were identified based on a probable match equal to or above $95 \%$. The selectivity of the deoxygenated products was determined based on Equation (2):

$$
X=\frac{A_{x}}{\sum A_{y}} \times 100 \%
$$

The term $X$ denotes the selectivity (\%), $A_{x}$ was determined by the peak area of the desired organic compound, and $A_{y}$ was determined by the peak area of the total organic compounds.

\section{Results and Discussion}

\subsection{WCO Evaluation as Biodiesel Feedstock}

Van et al. highlighted the number of carboxylic acid groups such as fatty acids in a mixture of chemical compounds [27]. Typically, a fixed amount of a sample is diluted in an organic solvent (usually isopropanol) and titrated with $\mathrm{KOH}$ (potassium hydroxide), using phenolphthalein as an essential colour indicator. Furthermore, the acid number measures the acidity of any substance, such as biodiesel. The volume of $\mathrm{KOH}$ (in $\mathrm{mg}$ ) required to neutralize the acidic constituents is $1 \mathrm{~g}$ of the sample. In this study, the three (3) WCO samples, and the acid values of their liquid oil products are shown in Table 2. The acidic and FFA values are expressed in Equations (3) and (4):

$$
\text { (Volume of } 0.01 \mathrm{M} \mathrm{KOH} \times 0.01 \times 56.1) / \text { Weight of oil }(\mathrm{g})
$$


Table 2. Acid values of WCO.

\begin{tabular}{ccc}
\hline Properties & WCO & Standard \\
\hline & A: 7.5592 & - \\
(i) FFA content (\%) & B: 11.7767 & \\
& C: 14.0520 & \\
& A: 3.7796 & ASTM D974 \\
(ii) Acid Value $\left(\mathrm{mg} \mathrm{KOH} \mathrm{g}^{-1}\right)$ & B. 5.8884 & \\
& C: 7.026 & ASTM D6751 (American standard \\
& A: 1.0727 & specification). EN14214 (European \\
(iii) Liquid Product (Biodiesel) & B: 0.6926 & standard specification) \\
\hline
\end{tabular}

However, the WCO feedstock was further subjected to chemical property characterization using GC programs adapted from Wan Khalit et al. [24], due to similarities in the source and locality obtained, as tabulated in Table 3.

Table 3. Composition of Fatty Acid ${ }^{\mathrm{a}}$.

\begin{tabular}{|c|c|}
\hline \multicolumn{2}{|c|}{ Fatty Acid Composition a (\%) } \\
\hline Myristic acid (C14) & 4.5 \\
\hline Palmitic acid (C16) & 22.0 \\
\hline Stearic acid (C18:0) & 2.1 \\
\hline Oleic acid (C18:1) & 48.1 \\
\hline Linoleic acid (C18:2) & 7.6 \\
\hline Gadoleic acid (C20:1) & 13.0 \\
\hline Others ${ }^{b}$ & 2.7 \\
\hline
\end{tabular}

\subsection{XRD Diffraction}

Figure 3 shows the XRD pattern of the analysed Ni-Mo/AC catalyst. There is an adjacent graph to the XRD peak distance, which is ascribed to the high crystallinity and clear elements of the mesoporous $\mathrm{Ni}-\mathrm{Mo} / \mathrm{AC}$ structure. Based on the graph, the intense peaks of $\mathrm{MoO}_{2}$ appeared at $2 \theta=26.033^{\circ}, 37.121^{\circ}, 49.498^{\circ}$, and $53.888^{\circ}$ (JCPDS card no: $00-002-0422)$. However, the $\mathrm{NiOOH}$ peaks were located at $\left.2 \theta=37.281^{\circ}\right)(\mathrm{JCPDS}$ card no: 00-006-0141). Furthermore, the visible peaks of $\mathrm{Ni}$ were found at $2 \theta=44.349^{\circ}, 51.674^{\circ}$ (JCPDS card no: 00-001-1272), whereas the $\mathrm{NiMoO}_{4}$ peaks were observed at $2 \theta=77.405^{\circ}$, $44.142^{\circ}, 52.488^{\circ}$ (JCPDS card no: 0120348). The results are in agreement with Wu et al. [28], who reported that the successful impregnation of $\mathrm{NiO}$ and $\mathrm{MoO}$ greatly reduced the amorphous structure of AC. Hence, the overlap of both species in AC ultimately promotes greater dispersal in the AC-based catalyst.

\subsection{Fourier Transform Infrared (FTIR) Spectroscopy}

Based on this study, the chemical functional groups of the triglyceride and deoxygenated products were studied. The spectra for all the samples in Figure 4 showed an absorption band detected at $1743 \mathrm{~cm}^{-1}(\mathrm{C}=\mathrm{O})$, that is ascribed to the ester groups in glycerides, whereas the band at $1140 \mathrm{~cm}^{-1}(\mathrm{C}=\mathrm{O})$ denotes the alcohol group usually attributed to WCO. The intense peak of the carbonyl $(\mathrm{C}=\mathrm{O})$ group and $\mathrm{WCO}$ are visible at $1740 \mathrm{~cm}^{-1}$. Hence, its presence at $1140 \mathrm{~cm}^{-1}$ indicates the progress of the DO reaction. The breakage of triglycerides into the fatty acids of the deoxygenated liquid can be observed through the shift in the $\mathrm{C}=\mathrm{O}$ (ester) absorption band from $1740 \mathrm{~cm}^{-1}$ to $1700 \mathrm{~cm}^{-1}$, which is ascribed to 
the intermediate carboxylic acid produced. The reaction phase for DO is also evident in the loss of the $\mathrm{C}=\mathrm{O}$ absorption band near $1150 \mathrm{~cm}^{-1}$. According to Satyarti and Srinivas [29], the typical C-H stretching peaks at $2921 \mathrm{~cm}^{-1}$ are not affected by hydrocarbon formation.

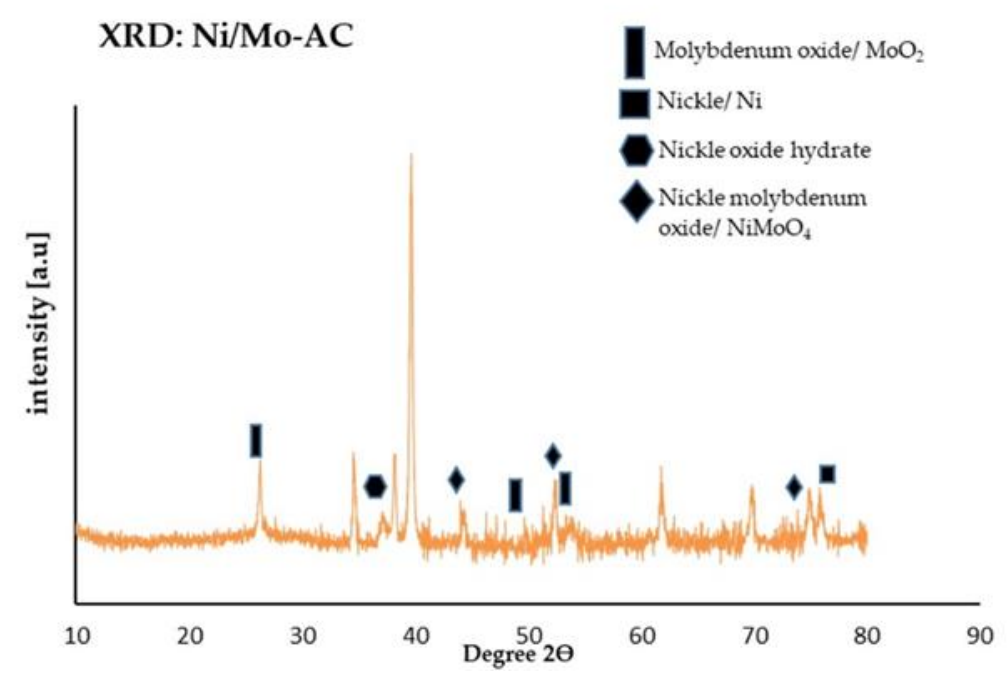

Figure 3. XRD diffraction of the calcined $\mathrm{NiO}-\mathrm{MoO} / \mathrm{AC}$ catalyst.

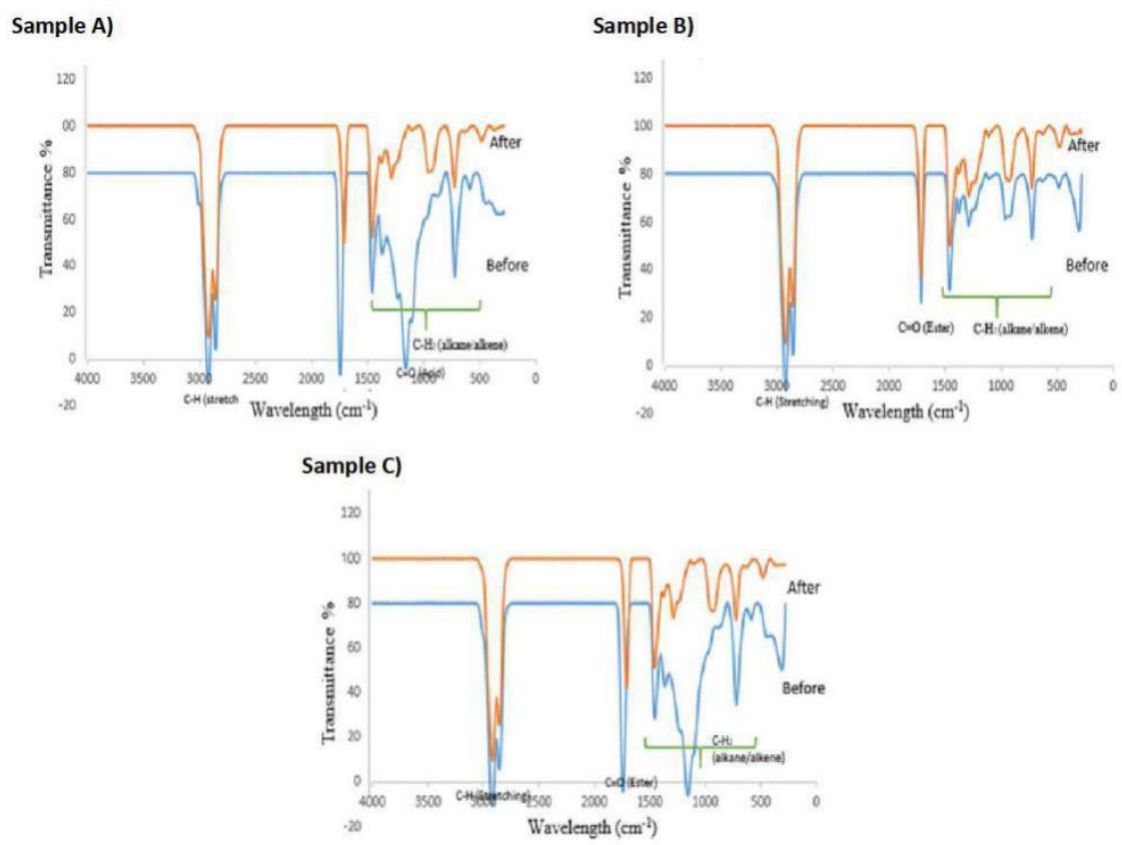

Figure 4. FTIR spectra of the deoxygenated sample (A-C) liquid product catalysed.

\subsection{Thermogravimetric Analysis (TGA)}

The degree of coke formation was investigated by TGA. In this study, the degree of coke formed on the Ni-Mo/AC catalyst is shown in Figure 5. Based on Figure 5a-(TGA $\mathrm{N}_{2}$ ), the calcined catalyst is defined by a shorter period or phase of coke formation and temperature range compared to the catalyst before calcination. The formation of coke on the external surface of the catalyst during the reaction degraded the DO activity. Hence, the results revealed that the bimetallic $\mathrm{Ni}-\mathrm{Mo} / \mathrm{AC}$ catalyst promotes superior resistance towards coke formation. The findings are in agreement with Wan Khalit et al. [24], who reported that the XRD and TGA confirm that the bimetallic Ni-Mo/AC has potential catalyst stability and prospects for further application at pilot-scale, due to its long-life and reuse. Figure $5 \mathrm{~b}-\left(\mathrm{TGA} \mathrm{O}_{2}\right)$ shows that the spent catalyst sample A exhibits a decomposition 
peak in the range $245^{\circ} \mathrm{C}$ to $347^{\circ} \mathrm{C}$. For sample B, the decomposition peak was from $252{ }^{\circ} \mathrm{C}$ to $319{ }^{\circ} \mathrm{C}$, whereas sample $\mathrm{C}$ was from $271{ }^{\circ} \mathrm{C}$ to $324{ }^{\circ} \mathrm{C}$, which is linked to the combustion of the AC bulk nanorod. In general, all the spent catalysts showed rapid weight loss due to the decomposition temperature at $700{ }^{\circ} \mathrm{C}$, which indicates the oxidation of coke in air.

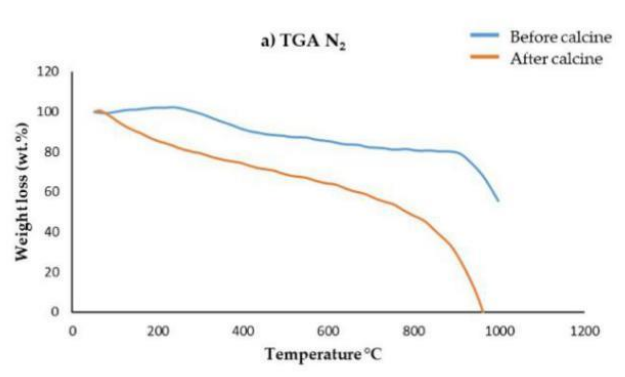

b)

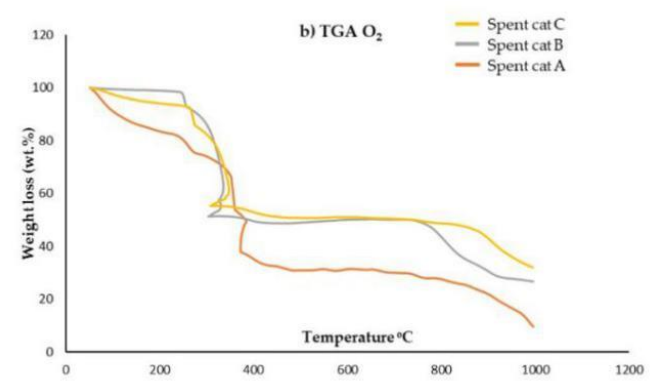

Figure 5. TGA profile for (a) before and after catalyst calcination in $\mathrm{N}_{2}$ and (b) spent catalyst sample $\mathrm{A}, \mathrm{B}, \mathrm{C}$ using $\mathrm{O}_{2}$.

\subsection{Field Emission Scanning Electron Microscopy (FESEM)}

Figure 6a illustrates the FESEM images of the fresh AC and Ni-Mo/AC catalyst at $700{ }^{\circ} \mathrm{C}$ activation temperature. The images represent a significant difference between the fresh AC and Ni-Mo/AC catalyst, which are characterized by smooth surfaces and regularshaped spheres. However, the morphology of the catalyst changed when the fresh AC was doped with the bimetal oxide. Hence, Figure $6 \mathrm{~b}$ shows rough, aggregate, and irregular spherical shapes with particle size $>1 \mu \mathrm{m}$. The changes are due to the occurrence of hydrogen bond fractures in the crystalline region triggered by the acid treatment of the activated charcoal surfaces, which assist in the formation of nanocrystalline fibrous-like structures or patterns [8]. The addition of the bimetallic phase of Ni-Mo/AC causes the enlargement of particle size, as expected from the combination of interposed metals $(\mathrm{NiO}+\mathrm{MoO})$ throughout the synthesis process. Thus, Table 4 below shows the elemental composition of the synthesized catalyst during the experimental process, as determined by EDX.
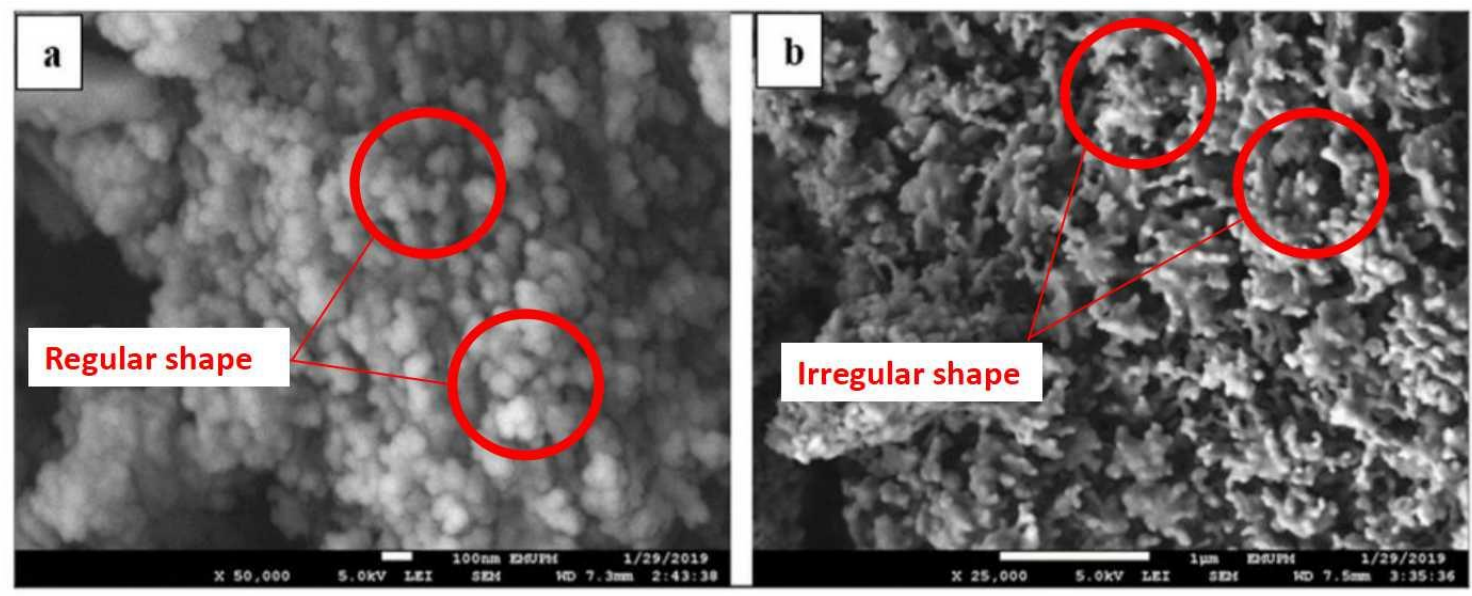

Figure 6. Field emission scanning electron microscopy (FESEM) image of (a) fresh AC, (b) Ni-Mo/AC catalyst. 
Table 4. Element composition of the catalyst determined by FESEM-EDX.

\begin{tabular}{ccccc}
\hline Catalyst $^{\mathbf{a}}$ & \multicolumn{4}{c}{ Element Composition (\%) } \\
\hline & $\mathbf{C}$ & $\mathbf{O}$ & $\mathbf{F e}$ & $\mathbf{N i}$ \\
\hline $\mathrm{AC}$ & 67.91 & 19.30 & - & - \\
$\mathrm{Ni}-\mathrm{Mo} / \mathrm{Ac}$ & 62.47 & 18.76 & 3.33 & 15.43 \\
\hline
\end{tabular}

a Theoretical Ni-Mo/AC atomic ratio of catalyst. ${ }^{\mathrm{b}}$ Experimental Ni-Mo/AC atomic ratio in synthesized catalyst determined by EDX.

\subsection{Biodiesel Properties}

\subsubsection{Gas Chromatography-Flame Ionization Detection}

The DO reactivity of WCO over Ni/Mo-AC catalyst is shown in Figure 7a,b. Based on Figure $7 \mathrm{a}$, sample $\mathrm{C}$ shows the highest yield of $31 \%$, followed by sample $\mathrm{A}(17 \%)$ and sample B (12\%). The significant values imply that the catalytic DO reaction was successful. The dark WCO showed the highest selectivity of DO due to the energetic effect of bimetallic $\mathrm{Ni} / \mathrm{Mo}$ on the AC nanorod, which enhanced the properties of the acid-base sites. Figure $7 \mathrm{~b}$ shows the comprehensive overview of the distribution of hydrocarbon portions from $n\left(\mathrm{C}_{8}{ }^{-}\right.$ $\mathrm{C}_{20}$ ) for the liquid DO products. The WCO consisting of $\sim 45.68 \% \mathrm{C}_{16}$ and $\sim 52.34 \% \mathrm{C}_{18}$ for fatty acids is typically converted to hydrocarbon portions comprising $n \mathrm{C}_{15}$ and $n \mathrm{C}_{17}$ by deCox pathways that are consistent with Bezergianni et al. [30].

a)

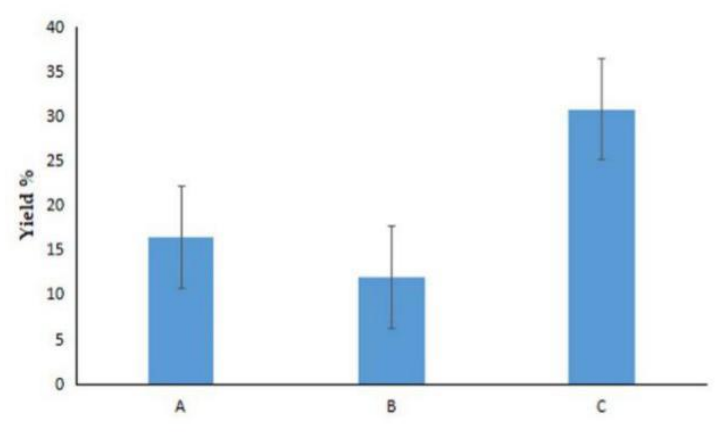

b)

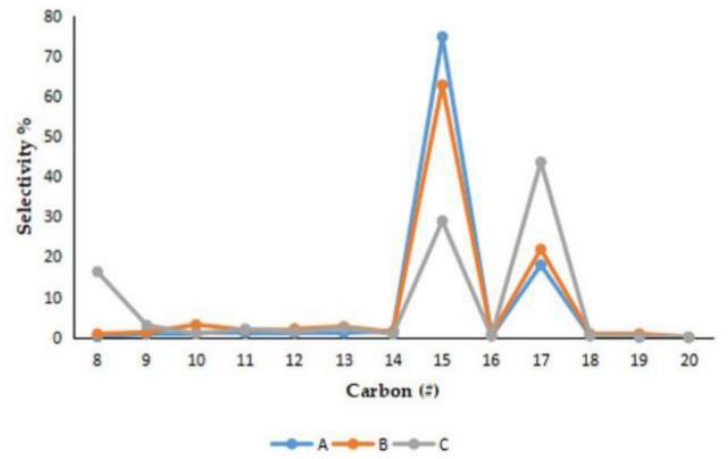

Figure 7. (a) Hydrocarbon yield \%, (b) Distribution of deoxygenation (DO) liquid products of samples A, B, and C using $\mathrm{Ni} / \mathrm{Mo}-\mathrm{AC}$.

\subsubsection{Gas Chromatography-Mass Spectrometry (GC-MS)}

The comprehensive distribution of products for all three WCO conditions using the $\mathrm{Ni}-\mathrm{Mo} / \mathrm{AC}$ catalyst at $350{ }^{\circ} \mathrm{C}$ is shown in Figure 8. According to the GC-MS results, the arrangement of the highest hydrocarbon fraction produced in the $n\left(\mathrm{C}_{8}-\mathrm{C}_{20}\right)$ range started from sample B $(89.93 \%)>$ sample C $(88.84 \%)>$ sample A (82.81\%). Lam et al. [31] reported that GC-MS analysis allows for easy detection of isomers based on the mass of the fragmented compound as suggested by the National Institute of Standards. Furthermore, the results of the different range of $n\left(\mathrm{C}_{8}-\mathrm{C}_{20}\right)$ hydrocarbons obtained from both GC-MS and GC-FID confirm that the straight-chained (saturated and unsaturated) hydrocarbons were mostly found in the liquid DO product. This result is in agreement with the finding in Section 3.3. However, a small amount of bulky $C_{21}-C_{24}$ hydrocarbons and oxygenated intermediates (such as aldehydes, ketones, alcohols, and carboxylic acid) were also detected. As reported by Silva [32], WCOs undergo various procedures to achieve a perfect breakdown of triglycerides into mono-chains (free-fatty acid). Other products include oxygenated DO intermediates, aldol condensation, ketonization and hydrocarbon deoxygenated cyclisation. 


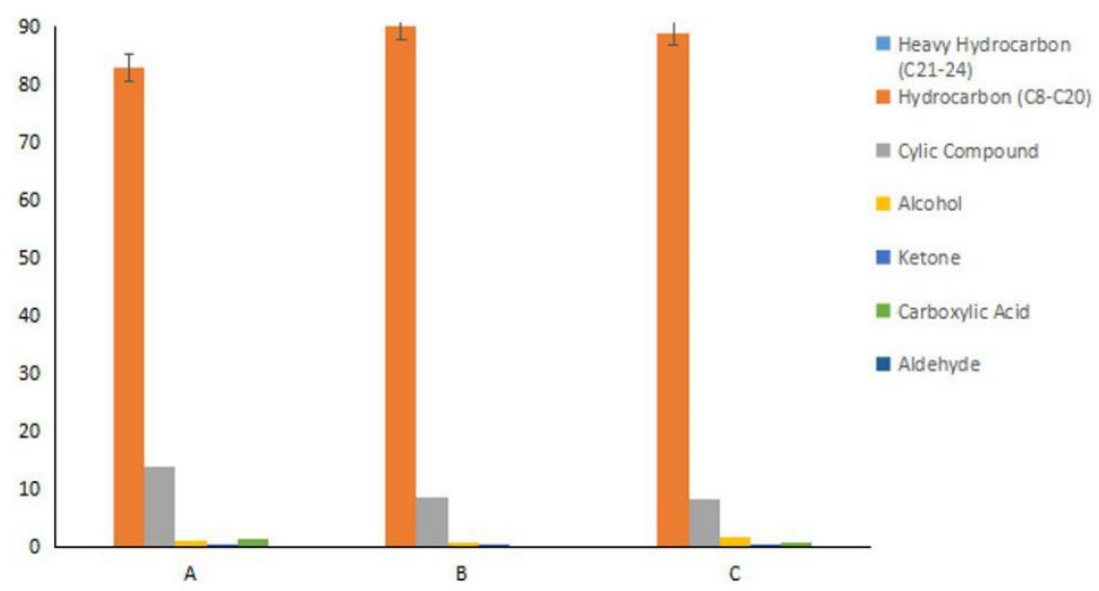

Figure 8. Distribution (\%) of DO liquid products from samples A, B and C catalysed by Ni-Mo/AC.

\section{Conclusions}

The remarkable activity of Ni-Mo/AC was due to the energetic effect between the active acidic promoter (Ni-Mo) and the extensive surface area of the AC support. Hence, an increase in the penetration of the large WCO triglycerides for the DO reaction was observed in this study. The yield of biodiesel obtained is influenced by the frequency of usage and type of food fried with the palm oil, which is due to chemical compounds released during the high cooking temperatures. Both samples A and B exhibited high hydrocarbon fraction yields of $89.93 \%$ and $88.84 \%$, respectively, at optimum conditions within $\mathrm{C}_{14}-\mathrm{C}_{18}$. In future studies, the authors propose to further investigate the current bimetallic acid catalyst, using different processes such as the transesterification of WCO to explore the potential of obtaining higher biodiesel yield and its cost-effectiveness in terms of catalyst stability and reusability. Other studies will synthesise different bimetallic catalysts with AC from different waste sources by altering the percentage ratios. The catalysts will then be examined for reactivity performance using WCO or other fatty acid sources, such as animal fat from poultry or plants that contains extractable triglyceride.

Author Contributions: N.S.A.: investigation and writing original draft, T.S.M.: Supervision, writing review and editing, A.-M.N.: Methodology, T.Y.Y.H.: Methodology and resources, N.K.: Funding acquisition, supervision, writing and review editing. All authors have read and agreed to the published version of the manuscript.

Funding: This research was funded by Geran Putra-Inisiatif Putra Berkumpulan (Grant number: 9671301) to support the research and development activities at Universiti Putra Malaysia Bintulu Sarawak Campus, Malaysia.

Data Availability Statement: Data available on request due to ethical restrictions.

Acknowledgments: The authors thank the Department of Basic Science and Engineering, Faculty of Agriculture and Food Science, University Putra Malaysia, Bintulu Sarawak Campus. Highest appreciation also goes to PutraCat UPM Serdang for the guidance, facilities, and instruments allowed for the project analysis to be done smoothly. The authors also thank the Research Management Centre of Universiti Putra Malaysia (UPM-IPB 9671301) and (Putra-IPM 9559000) for supporting this study.

Conflicts of Interest: The authors declare no conflict of interest. 


\section{References}

1. Asikin-Mijan, N.; Lee, H.V.; Juan, J.C.; Noorsaadah, A.R.; Abdulkareem-Alsultan, G.; Arumugam, M.; Taufiq-Yap, Y.H. Waste clamshell-derived $\mathrm{CaO}$ supported $\mathrm{Co}$ and $\mathrm{W}$ catalysts for renewable fuels production via cracking-deoxygenation of triolein. J. Anal. Appl. Pyrolysis 2016, 120, 110-120. [CrossRef]

2. Arun, N.; Sharma, R.V.; Dalai, A.K. Green diesel synthesis by hydrodeoxygenation of bio-based feedstocks: Strategies for catalyst design and development. Renew. Sustain. Energy Rev. 2015, 48, 240-255. [CrossRef]

3. Hajinezhad, A.; Abedi, S.; Ghobadian, B.; Noorollahi, Y. Biodiesel production from Norouzak (Salvia lerifolia) seeds as an indigenous source of bio fuel in Iran using ultrasound. Energy Convers. Manag. 2015, 99, 132-140. [CrossRef]

4. Asikin-Mijan, N.; Lee, H.V.; Taufiq-Yap, Y.H.; Juan, J.C.; Rahman, N.A. Pyrolytic-deoxygenation of triglyceride via natural waste shell derived $\mathrm{Ca}(\mathrm{OH})_{2}$ nanocatalyst. J. Anal. Appl. Pyrolysis 2016, 117, 46-55. [CrossRef]

5. Asikin-Mijan, N.; Lee, H.V.; Taufiq-Yap, Y.H.; Abdulkrem-Alsultan, G.; Mastuli, M.S.; Ong, H.C. Optimization study of SiO ${ }_{2}-$ $\mathrm{Al}_{2} \mathrm{O}_{3}$ supported bifunctional acid-base $\mathrm{NiO}-\mathrm{CaO}$ for renewable fuel production using response surface methodology. Energy Convers. Manag. 2017, 141, 325-338. [CrossRef]

6. Zhang, Y.; Bi, P.; Wang, J.; Jiang, P.; Wu, X.; Xue, H.; Liu, J.; Zhou, X.; Li, Q. Production of jet and diesel biofuels from renewable lignocellulosic biomass. Appl. Energy 2015, 150, 128-137. [CrossRef]

7. Choudhary, T.V.; Phillips, C.B. Renewable fuels via catalytic hydrodeoxygenation. Appl. Catal. A Gen. 2011, 397, 1-12. [CrossRef]

8. Echeandia, S.; Arias, P.L.; Barrio, V.L.; Pawelec, B.; Fierro, J.L.G. Synergy effect in the HDO of phenol over Ni-W catalysts supported on active carbon: Effect of tungsten precursors. Appl. Catal. B Environ. 2010, 101, 1-12. [CrossRef]

9. Romero, M.J.A.; Pizzi, A.; Toscano, G.; Busca, G.; Bosio, B.; Arato, E. Deoxygenation of waste cooking oil and non-edible oil for the production of liquid hydrocarbon biofuels. Waste Manag. 2016, 47, 62-68. [CrossRef]

10. Kim, S.K.; Han, J.Y.; Hong, S.A.; Lee, Y.W.; Kim, J. Supercritical $\mathrm{CO}_{2}$-purification of waste cooking oil for high-yield diesel-like hydrocarbons via catalytic hydrodeoxygenation. Fuel 2013, 111, 510-518. [CrossRef]

11. Chen, L.; Zhu, Y.; Zheng, H.; Zhang, C.; Li, Y. Aqueous-phase hydrodeoxygenation ofpropanoic acid over the $\mathrm{Ru} / \mathrm{ZrO}_{2}$ and $\mathrm{Ru}-\mathrm{Mo} / \mathrm{ZrO}_{2}$ catalysts. Appl. Catal. A Genera 2012, 411, 95-104. [CrossRef]

12. Ausavasukhi, A.; Huang, Y.; To, A.T.; Sooknoi, T.; Resasco, D.E. Hydrodeoxygenation of m-cresol over gallium-modified beta zeolite catalysts. J. Catal. 2012, 290, 90-100. [CrossRef]

13. Ayodele, O.B.; Togunwa, O.S.; Abbas, H.F.; Daud, W.M.A.W. Preparation and characterization of alumina supported nickeloxalate catalyst for the hydrodeoxygenation of oleic acid into normal and iso-octadecane biofuel. Energy Convers. Manag. 2014, 88, 1104-1110. [CrossRef]

14. Rezgui, Y.; Guemini, M. Effect of acidity and metal content on the activity and product selectivity for n-decane hydroisomerization and hydrocracking over nickel-tungsten supported on silica-alumina catalysts. Appl. Catal. A: Gen. 2005, 282, 45-53. [CrossRef]

15. Chen, J.; Shi, H.; Li, L.; Li, K. Deoxygenation of methyl laurate as a model compound to hydrocarbons on transition metal phosphide catalysts. Appl. Catal. B Environ. 2014, 144, 870-884. [CrossRef]

16. Morgan, T.; Grubb, D.; Santillan-Jimenez, E.; Crocker, M. Conversion of triglycerides to hydrocarbons over supported metal catalysts. Top. Catal. 2010, 53, 820-829. [CrossRef]

17. Miao, C.; Marin-Flores, O.; Davidson, S.D.; Li, T.; Dong, T.; Gao, D.; Wang, Y.; Garcia-Pérez, M.; Chen, S. Hydrothermal catalytic deoxygenation of palmitic acid over nickel catalyst. Fuel 2016, 166, 302-308. [CrossRef]

18. Martin, S.; Kraaij, G.; Ascher, T.; Wails, D.; Wörner, A. An experimental investigation of biodiesel steam reforming. Int. J. Hydrogen Energy 2015, 40, 95-105. [CrossRef]

19. Abdulkareem-Alsultan, G.; Asikin-Mijan, N.; Lee, H.V.; Taufiq-Yap, Y.H. A new route for the synthesis of La-Ca oxide supported on nano activated carbon via vacuum impregnation method for one pot esterification-transesterification reaction. Chem. Eng. J. 2016, 304, 61-71. [CrossRef]

20. Sen, A.; Pramanik, P. Low-temperature synthesis of nano-sized metal molybdate powders. Mater. Lett. 2001, 50, 287-294. [CrossRef]

21. Sen, A.; Pramanik, P. A chemical synthetic route for the preparation of fine-grained metal molybdate powders. Mater. Lett. 2002, 52, 140-146. [CrossRef]

22. Festel, G.; Bellof, M.; Wurmseher, M. Calculation of raw material prices and conversion costs for biofuels. In Liquid Biofuels: Emergence, Development and Prospects; Springer: London, UK, 2014; pp. 93-115.

23. Chhetri, A.; Watts, K.; Islam, M. Waste Cooking Oil as an Alternate Feedstock for Biodiesel Production. Energies 2008, 1, 3. [CrossRef]

24. Adira Wan Khalit, W.N.; Marliza, T.S.; Asikin-Mijan, N.; Gamal, M.S.; Saiman, M.I.; Ibrahim, M.L.; Taufiq-Yap, Y.H. Development of bimetallic nickel-based catalysts supported on activated carbon for green fuel production. RSC Adv. 2020, 10, 37218-37232. [CrossRef]

25. Asomaning, J.; Mussone, P.; Bressler, D.C. Thermal deoxygenation and pyrolysis of oleic acid. J. Anal. Appl. Pyrolysis 2014, 105, 1-7. [CrossRef]

26. Asikin-Mijan, N.; Lee, H.V.; Marliza, T.S.; Taufiq-Yap, Y.H. Pyrolytic-deoxygenation of triglycerides model compound and non-edible oil to hydrocarbons over SiO2-Al2O3 supported NiO-CaO catalysts. J. Anal. Appl. Pyrolysis 2018, 129, 221-230. [CrossRef] 
27. Van Gerpen, J.; Shanks, B.; Pruszko, R.; Clements, D.; Knothe, G. Biodiesel Analytical Methods August 2002-January 2004; No. Nrel/Sr-510-36240; National Renewable Energy Lab.: Golden, CO, USA, 2004.

28. Wu, J.; Xia, Q.; Wang, H.; Li, Z. Catalytic performance of plasma catalysis system with nickel oxide catalysts on different supports for toluene removal: Effect of water vapor. Appl. Catal. B Environ. 2014, 156-157, 265-272. [CrossRef]

29. Satyarthi, J.K.; Srinivas, D. Fourier transform infrared spectroscopic method for monitoring hydroprocessing of vegetable oils to produce hydrocarbon-based biofuel. Energy Fuels 2011, 25, 3318-3322. [CrossRef]

30. Bezergianni, S.; Voutetakis, S.; Kalogianni, A. Catalytic hydrocracking of fresh and used cooking oil. Ind. Eng. Chem. Res. 2009, 48, 8402-8406. [CrossRef]

31. Lam, S.S.; Russell, A.D.; Lee, C.L.; Chase, H.A. Microwave-heated pyrolysis of waste automotive engine oil: Influence of operation parameters on the yield, composition, and fuel properties of pyrolysis oil. Fuel 2012, 92, 327-339. [CrossRef]

32. Silva, L.N.; Fortes, I.C.P.; de Sousa, F.P.; Pasa, V.M.D. Biokerosene and green diesel from macauba oils via catalytic deoxygenation over Pd/C. Fuel 2016, 164, 329-338. [CrossRef] 